\title{
Strategies for Teacher Education Programs to Support Indigenous Teacher Employment and Retention in Schools
}

Danielle Tessaro

University of Victoria

Laura Landertinger

Hartwick University

Jean-Paul Restoule

University of Victoria

\begin{abstract}
This article seeks to contribute to the knowledge base regarding efforts to increase the supply of employed Indigenous teachers. In addition to supporting the learning and well-being of Indigenous students, increasing Indigenous teachers is critical for remote Indigenous
\end{abstract}

Canadian Journal of Education / Revue canadienne de l'éducation 44:3 (2021)

(02021 Canadian Society for the Study of Education/ Société canadienne pour l'étude de l'éducation 
communities with chronically understaffed schools. This study was conducted as a scoping review of 50 Teacher Education Programs (TEPs) across Canada, Australia, New Zealand, and the United States that have enacted efforts to increase Indigenous teachers. The study found a range of effective strategies, and this article will depict three strategies that can be enacted by TEPs to support Indigenous teacher graduates as they transition to employment. The strategies are: (1) creating employment opportunities, (2) identifying community needs and collaborating over practicum placements, and (3) providing ongoing support. The article concludes with a call for collaboration, funding, and data collection for the continued evaluation and improvement of strategies to increase Indigenous teachers.

Keywords: teacher retention, teacher support, teacher employment, Indigenous teacher education, job transition, Indigenous teachers, Indigenous education, teacher education programs

\section{Résumé}

Ce document cherche à contribuer à la base de connaissances sur les efforts visant à accroître l'offre d'enseignants autochtones en activité. En plus de soutenir l'apprentissage et le bien-être des élèves autochtones, il est essentiel d'augmenter le nombre d'enseignants autochtones pour les communautés autochtones éloignées dont les écoles sont en souseffectif chronique. Cette étude a été menée dans le cadre d'un examen de la portée de 50 programmes de formation des enseignants (TEP) à travers le Canada, l'Australie, la Nouvelle-Zélande et les États-Unis qui ont mis en œuvre des efforts pour augmenter le nombre d'enseignants autochtones. L'étude a trouvé une gamme de stratégies efficaces et cet article décrit trois stratégies qui peuvent être mises en œuvre par les TEP pour aider les enseignants diplômés autochtones dans leur transition vers l'emploi. Ces stratégies sont : (1) de créer des possibilités d'emploi, (2) d'identifier les besoins de la collectivité et de collaborer à leur placement en stage, et (3) de leur fournir un soutien continu. Le document se termine par un appel à la collaboration, au financement et à la collecte de données pour l'évaluation continue et l'amélioration des stratégies visant à accroître le nombre d'enseignants autochtones.

Mots-clés : rétention des enseignants, soutien aux enseignants, embauche d'enseignants, formation d'enseignants autochtones, transition vers l'emploi, enseignant autochtone, éducation autochtone, formation des enseignants 


\section{Introduction}

This article discusses several strategies that are employed by Universities, Colleges, and Teacher Education Programs ${ }^{1}$ (TEPs) to support Indigenous students as they transition into their roles as teachers. The study contributes to a collective body of work aiming to increase the number of Indigenous teachers in schools. In March of 2020, as the impacts and realities of COVID-19 led to school closures throughout Canada and many parts of the world, students and their parents were forced to adjust to at-home learning. For most families, the sudden shift to at-home learning presented a wide set of difficulties. For instance, students struggled to find appropriate study space to focus, and parents struggled to support their children's learning, and to find the time to do so. As quoted from one parent in an article by $C B C$ News (Wong, 2020), "It was like pulling teeth trying to get him to do even small parts of the assigned work, and I was just frustrated beyond belief" (n.p.).

Unfortunately, for many Indigenous and remote communities across Canada and abroad, the challenges of a sudden shift to at-home learning and classroom closures are nothing new. Class cancellations are common lived realities for those attending school in remote, Indigenous communities. Each school year, schools such as the Kisemattawa Kiskinwahamakew Kamik School of Shamattawa First Nation in northern Manitoba are forced to temporarily cancel classes or to teach certain grades every other day (Caruk, 2018). In instances such as these, students are provided with take-home learning packages, as alternatives to in-school learning (Coubrough, 2017). Unlike the experience of many Canadians in March of 2020, the reasons for frequent classroom closures and athome learning in remote Indigenous communities is not a global pandemic, but a chronic shortage of teachers employed in their schools.

By depicting means of TEP support strategies for Indigenous teachers as they enter into teaching roles, this study contributes to a critical body of work that aims to increase the number of Indigenous teachers employed and remaining in schools. Overall, increasing the number of Indigenous teachers employed in schools is important for

1 Going forward, the phrase Universities, Colleges and Teacher Education Programs (TEPs) is simplified into "TEPs." In this study, "TEPs" refers to any of the TEPs or collaborations run through universities, colleges, and faculties, departments, or divisions of education that were included in our data. 
supporting Indigenous students and their families, and to ensure that schools are able to remain open, operational, and stable. Increasing the number of Indigenous teachers is critical for the educational outcomes and well-being of Indigenous students (Battiste \& McLean, 2005; Council of Ministers of Education, Canada [CMEC], 2010; Malatest \& Associates, 2010; Whitinui et al., 2018), and for the staffing of chronically under-staffed schools in remote communities with predominantly Indigenous populations (Hall, 2012; Somerville \& Rennie, 2012; Yarrow et al., 1999).

In addition to increasing the number of Indigenous teachers, it is equally important to retain them. High rates of teacher turnover can have detrimental impact on schools and their students (Hall, 2012; Holme et al., 2018; Papay et al., 2017; Weldon, 2018). Improving teacher retention in Indigenous communities will have positive impacts for learning outcomes of students in those communities (Cherng \& Halpin, 2016; Hall, 2012; Holme et al., 2018; Somerville \& Rennie, 2012). For instance, years of sustained teaching experience can be a factor contributing to better quality teaching, and better quality teaching contributes to better quality learning (Hall, 2012; Holme et al., 2018).

Indigenous teachers are more likely than non-Indigenous teachers to remain teaching for longer periods of time in Indigenous communities, especially in their home communities (Fovet \& Hall, 2012; Hall, 2012; Landertinger et al., 2020). On a profound level, the reason for this is that it is their home. In their home communities, teachers feel they belong (Somerville \& Rennie, 2012) and are more likely to want to make positive contributions to that community. Other factors contributing to the better longevity of Indigenous teachers employed in Indigenous communities may include the ability to tailor teaching practices flexibly "for the specific needs of remote Indigenous students," and openness to "cross-cultural collaboration with Indigenous teachers and communities" (Hall, 2012, p. 194).

In contrast, non-Indigenous teachers are less likely to remain in schools in Indigenous communities. The literature offers various explanations for the high turnover rates of non-Indigenous teachers in Indigenous communities. For instance, they are less likely to be able to adapt a curriculum suited to Indigenous cultural context (Hall, 2012; Hickling-Hudson \& Ahlquist, 2003; Murray-Orr \& Mitton-Kukner, 2017) and they may perceive remote Indigenous communities as "abject place[s] of deficit and disadvantage" instead of "a cosy place of belonging and comfort" (Somerville \& Rennie, 2012, p. 193). What must be added to this literature is the recognition that non-Indigenous teachers are 
only able to access these communities based on the histories and contemporary realities of dispossession and colonization. The issues raised of non-Indigenous teacher attrition, along with higher likelihoods of Indigenous teacher retention in Indigenous communities, underlines the need for practices that aim for an overall increase in Indigenous teachers. Better supporting Indigenous students and their school experience, thereby increasing the number of Indigenous teachers working in and remaining in remote and Indigenous schools, ultimately benefits the families of those students, and the communities at-large.

For the purposes of this study, data were collected from over 50 TEPs that have enacted efforts to increase the number of Indigenous teachers graduating from their programs. Data were collected from TEP websites, online reports and online media, and phone calls and emails with knowledgeable TEP staff. TEP data were organized according to the type of strategy, including: (1) Indigenous student recruitment, (2) student retention, and/or (3) job transition and employment support. While existent literature discusses TEP recruitment and retention strategies for Indigenous students (Buckskin, 2016; Landertinger et al., 2020), recent studies have yet to discuss support strategies enacted by TEPs for Indigenous teachers after they graduate, which is the focus of this article.

An analysis of the job transition data revealed several main themes, which have been summarized into three main actionable strategies for TEPs to support Indigenous teachers after graduation. Briefly, the strategies to be discussed in this article are: (1) the creation of teaching positions, (2) identification of community needs and collaboration over practicum placements, and (3) ongoing support for newly employed teachers.

Although the problem of beginner teacher attrition concerns all groups of teachers (Holme et al., 2018; Papay et al., 2017; Weldon, 2018), this study focused on supporting new teachers who identify as Indigenous, aligning with crucial reconciliation efforts to increase the number of Indigenous teachers in the study regions of Australia, New Zealand, Canada and the United States (Reconciliation Australia, 2016; Truth and Reconciliation Commission, 2015; Truth and Reconciliation Commission of Canada, 2015). It must be emphasized that the authors do not believe that the strategies can act as standalone steps toward reconciliation. In fact, the situation is quite the opposite. After centuries of decimation at the hands of colonial populations in the case regions, reconciliation requires a complete overhaul of ideologies that shape existent sectors of society including government, healthcare, police enforcement, the judicial system, and education (CMEC, 2010; Reconciliation Australia, 2016; Truth and Reconciliation Commission, 2015; Truth 
and Reconciliation Commission of Canada, 2015). Across education sectors, not only do more Indigenous teachers need to be employed, as is the broad topic of our study, but education and curricula must transition away from purely Eurocentric perspectives. Indigenous histories and perspectives must become more prominent (Battiste \& McLean, 2005; Hickling-Hudson \& Ahlquist, 2003; Kirkness, 1999), fundamentally transforming education into an arena that fosters Indigenous sovereignty and self-governance (Anthony-Stevens et al., 2017; National Indian Education Association, 2018; Zingg, 2019). Our study narrows its focus to the role of TEPs in the hopes of contributing to the broader efforts in the field of Indigenous education (McKinley \& Smith, 2019; Kitchen \& Raynor, 2013; Nardozi et al., 2014; Whitinui et al., 2018), and it is through these small pieces that we hope to one day see adequate levels of change.

\section{Methods}

This article is part of a larger research project, led by the authors, which sought to identify successful strategies enacted by TEPs that led to an increase of employed Indigenous teachers (see example, Table 1). The study used the methodology of a scoping review (Arksey \& O'Malley, 2005) of TEPs operating at colleges and universities across Canada, the United States, Australia, and New Zealand. These countries were selected for showing an actual increase in numbers of employed Indigenous teachers (Association of BC Deans of Education [ABCDE], 2018), making them good candidates for the study. By collecting data from TEP programs across Canada and select TEPs abroad, the goal of the scoping review method was to "systematically map the range of available strategies, to analyze these strategies according to their outcomes, and to provide a summarized list of corresponding findings and recommendations" (Landertinger et al., 2020, p. 38). 


\section{Table 1}

\section{Excerpt from Data Table Used for the Full Study}

\begin{tabular}{|c|c|c|}
\hline $\begin{array}{l}\text { Teacher Education } \\
\text { Program (TEP) }\end{array}$ & $\begin{array}{l}\text { Strategies, actions, policies or } \\
\text { programs to increase employed } \\
\text { Indigenous teachers }\end{array}$ & $\begin{array}{l}\text { Result showing Indigenous } \\
\text { teacher employment }\end{array}$ \\
\hline $\begin{array}{l}\text { Program for the Education } \\
\text { of Native Teachers (PENT) } \\
\text { at Brandon University }\end{array}$ & $\begin{array}{l}\text { PENT is a community-based teacher } \\
\text { education program through which } \\
\text { students combine paraprofessional work } \\
\text { in their community schools } \\
\text { (September-March). One of the } \\
\text { entrance requirements stipulates that } \\
\text { prospective students must already be } \\
\text { working in a school as a classroom } \\
\text { paraprofessional (e.g., teacher's aide) } \\
\text { (PENT, 2015). Students are selected by } \\
\text { the sending community. } \\
\text { Graduates must apply for certification to } \\
\text { Manitoba Education. } \\
\text { An advisory committee oversees the } \\
\text { delivery of PENT, made up of } \\
\text { representatives from the Manitoba } \\
\text { Métis Federation, Southeast Resource } \\
\text { Development Council, Keewatin Tribal } \\
\text { Council, West Region Tribal Council, } \\
\text { Dakota Ojibway Tribal Council, } \\
\text { Interlake Reserves Development } \\
\text { Council, Frontier School Division, } \\
\text { the PENT. Student Body, Manitoba } \\
\text { Teachers' Society, Director of Teacher } \\
\text { Certification \& Records, Department } \\
\text { of Education, Faculty of Education and } \\
\text { PENT staff (PENT, 2015). } \\
\text { The program takes, on average, six } \\
\text { years to complete. A } 40 \text {-month } \\
\text { internship is completed over the course } \\
\text { of the program. Students work within a } \\
\text { school before the program, throughout } \\
\text { the program and upon completion. }\end{array}$ & $\begin{array}{l}\text { Over } 50 \text { schools across central } \\
\text { and northern Manitoba } \\
\text { participate in PENT (Brandon } \\
\text { University, 2020). According to } \\
\text { the PENT student handbook for } \\
\text { the year 2015-2016, over } 587 \\
\text { graduates teach in schools in } \\
\text { Manitoba and other provinces } \\
\text { (PENT, 2015). }\end{array}$ \\
\hline
\end{tabular}

Data collection began with gathering publicly available information from online sources including reports, media sources and TEP website, and university or government webpages. In many instances, the researchers followed up with relevant TEP 
administrators using publicly listed emails or telephone numbers, to confirm or collect additional data. Data were gathered from over 50 TEPs and collection took place over six months, ending in mid-2018. The 50 TEPs included 36 programs from across Canada, and the remainder from institutions in Australia, New Zealand, and the United States. Data were entered into an extensive table (approximately 80 pages) to paint a picture of the range of available and applied TEP strategies. The table listed each of the 50 TEPs with strategies applicable to the study, with columns pertaining to: (1) the strategy (or strategies) or action(s) directed at increasing the number of Indigenous teachers, and (2) the results of the strategy, if available (see sample, Table 1).

The data entered into column number two, pertaining to the results of the strategy, helped the researchers to assess whether a strategy was effective or not. For instance, strategies such as Australia's More Aboriginal and Torres Strait Islander Teachers Initiative (MATSITI) published online reports indicating numerical increases in Aboriginal and Torres Strait Islander teachers working across target regions. Data entered into column two thus included quantitative figures from reports, websites, or online literature, as well as qualitative feedback from TEP students or graduates, administrators, or Indigenous community partners. Data concerning tangible results were difficult to attain for many TEPs, as it is not regularly or thoroughly collected and/or published.

The resulting data table depicted a wide range of strategies employed by TEPs to increase or support Indigenous teachers, along with the relative effectiveness of the strategies. From there, the data entered into column number one-pertaining to strategies employed by the relevant TEP to increase Indigenous teachers - was organized according to strategy "type" (see Table 2). That is, it was found that various main themes emerged from the data, in that the strategies enacted by certain TEPs overlapped with the strategies enacted by other TEPs, in terms of what aspect of their program they sought to address and/or how they sought to address it. 


\section{Table 2}

Strategies According to Theme, with Examples from the Data

Strategy type or theme

Creating employment opportunities
Identifying community needs and collaborating over practicum placements

\section{Example strategies, policies, actions, or programs}

More Aboriginal and Torres Strait Islander Teachers Initiative (MATSITI) Join Our Mob campaign, created by New South Wales Department of Education. Partnership initiative includes:

- Scholarship program under which 80 Aboriginal and Torres Strait Islander people are financially supported to train as teachers.

- A guaranteed appointment in a preferred location upon graduation. Several US states have utilized funding for expanding Indigenous teacher pool by creating teaching positions. These states include Arizona, Minnesota, Montana, Nebraska, Oklahoma, Oregon, and South Dakota.

- Teacher Education Programs then train for these newly created jobs. Programs establish employment positions directly with communities searching for teachers before students graduate.

- $\quad$ For example, University of Nebraska-Lincoln's Indigenous Roots Teacher Education Program (ROOTS) partners with communities looking for Indigenous teacher graduates to work.

- $\quad$ The Aboriginal Teacher Education Program (ATEP) at the University of Alberta trains its students with the objective of having them placed in rural areas (with the exception of the urban cohort). Students complete two years of course work at one of the four colleges, after which they complete two more years of professional training in schools close to home. The aim is to find employment for the students in these communities.

- Through government and Teacher Education Program (TEP) partnerships, MATSITI partners with communities in need of teachers. Teacher candidates from these communities complete practicums in these locations.

- Yukon Native Teacher Education Program (YNTEP), a program offered through a partnership by University of Regina/Yukon College, includes two field placements and extensive practicum experiences throughout four years in Yukon and rural areas.

- In the Nunavut Teacher Education Program (NTEP) by the University of Regina and Nunavut Arctic College, students complete practica in schools under an agreement that this is where they will be employed afterward. The community schools and the District Education Authority (DEA) collaborate through NTEP to select the teacher candidate who will be supported through the home-based Teacher Education Program (TEP), complete their practicum within the school, and work there afterward.

- Through Lakehead University, the Office of Aboriginal Cultural and Support Services offers employment assistance to Indigenous students, including referrals to job opportunities and employment and training opportunities. 


\begin{tabular}{ll}
\hline Strategy type or theme & Example strategies, policies, actions, or programs \\
\hline Providing ongoing support & At Southeastern Oklahoma State University, after graduation, teach- \\
ers receive continued specialized training and support throughout & their first year of employment. \\
- & The Aboriginal Teacher Education Program (ATEP) at the Universi- \\
& ty of Alberta offers extra professional development throughout and \\
& after graduation to expose teacher candidates to Indigenous teaching \\
& resources. \\
& University of Oregon's Sapsik'wałá (Teacher) Education Program \\
& provides a full year of support services after graduates begin teach- \\
& ing. This includes “provision of a mentor, formative evaluations of \\
& your teaching, support for attendance at a professional conference, \\
& cohort seminar meetings, an electronic distribution and discussion \\
list, and access to the virtual curriculum and research center" (Uni- & versity of Oregon, 2012). \\
North Arizona University’s Hopi Teachers for Hopi Schools follows \\
up with the teacher graduates, visits them and maintains regular \\
discussion.
\end{tabular}

Overall, 11 main themes emerged in terms of strategy "type." Briefly, the 11 themes or strategy types are: bringing the education to the students, removing financial barriers, providing alternative pathways to admission and certification, creating Indigenous cohorts, providing specialized support services, providing Indigenous-centric curriculum and program design, drawing from Indigenous pedagogies, hiring Indigenous faculty and educators, creating employment opportunities, identifying community needs and collaborating over practicum placements, and providing ongoing support. These 11 main themes found across the TEP strategies were then further grouped according to three relative stages of Indigenous teacher support: recruitment, retention, and job transition or post-graduation support. Notably, the first eight of the 11 main strategy types broadly fall under strategies for recruitment and retention of Indigenous teacher candidates. Each of these strategies is discussed in a separate article by the authors (Landertinger et al., 2020). The following article will instead depict the final three of the 11 themes (creating employment opportunities, identifying community needs and collaborating over practicum placements, and providing ongoing support), which indicate findings for TEP strategies to support Indigenous teacher graduates entering into teaching positions. While the TEP recruitment and retention strategies discussed in Landertinger et al. (2020) seek to increase the number of Indigenous people certified as teachers, the strategies described in this article are intended to provide guidance on how to support Indigenous teacher graduates 
to transition into teaching roles, ideally reducing the rates of teacher turnover in remote, Indigenous communities.

\section{Findings}

The study found three main themes across the data that speak to strategies employed by TEPs to support recent Indigenous teacher graduates as they transition into teaching positions. The overall idea of the strategies is to increase the number of newly certified Indigenous teachers in schools and reduce early attrition of these newly employed teachers. Each of the strategies is described and exemplified below, beginning with the creation of employment opportunities.

\section{Strategy 1: Creating Teaching Positions}

The most successful strategy applied by TEPs to support Indigenous teacher graduates is to create employment opportunities. While the strategy sounds obvious, it is an important and effective tool for TEPs in supporting their Indigenous students after graduation. It is a common strategy in the United States, where federal funding has been made available and directed toward expanding the Indigenous teacher pool (US Department of Education, 2017). TEPs in Arizona, Minnesota, Montana, Nebraska, Oklahoma, Oregon, and South Dakota have used the funding to work with communities in establishing the teaching positions that their students work toward. These TEPs will admit a cohort of Indigenous teacher candidates and train them with specific jobs in mind, usually at schools in their home communities.

Such cohorts are often fully funded, which is a primary recruitment and retention strategy enacted by TEPs (Landertinger et al., 2020). Once that cohort completes their teacher training and are employed, the TEP moves on to the next cohort. Program intake may only happen every few years, but once admitted, teacher candidates are supported through the entire process, from admission to employment. As described by the coordinator of the ROOTS program at the University of Nebraska-Lincoln, this strategy is a "win-win-win" situation: "You get teachers for school districts that need them and teachers who are deeply committed to the success of their students" (Engen-Wedin, as quoted in Stauffer, 2017, n.p.). 
A similar approach was found by Australia's More Aboriginal and Torres Strait Islander Teachers Initiative (MATSITI). MATSITI was a five-year (2011-2016) employment initiative to increase the number of Aboriginal and Torres Strait Islander people entering into and remaining in teaching positions across Australia. Through its years of operation and data collection, the program placed 697 teachers who identify as Indigenous in teaching positions across the country (Buckskin, 2016). The project began with a \$7.5 million funding agreement between the Australian government and the University of South Australia, which extended to 57 smaller partnership project agreements. One partnership project involved the creation of the "Join Our Mob" campaign, led by the New South Wales Department of Education. The campaign provided full scholarships and some additional financial support to 80 Aboriginal and Torres Strait Islander peoples to be trained as teachers. Upon graduation, the teachers received a guaranteed appointment in a preferred location.

Of the case countries, Canada alone lacks an equivalent strategy. In fact, the data revealed a glaring absence of TEP employment and job transition initiatives for Indigenous teachers in Canada. While practicums prepare teacher candidates well for employment, and while many Canadian universities offer career advice, such as résumé clinics or interview preparation, actual employment opportunities can be scarce, assistance with job placements is limited, and guaranteed appointments are virtually nonexistent. As opposed to faulting the Canadian TEPs, the creation of teaching positions depends on provincial and federal investments that fall short in the Canadian context. The lack of employment opportunities is a direct result of federal, provincial, and territorial governments underfunding education generally, and Indigenous education specifically. Currently, in rightwing party-led provinces, such as Ontario ${ }^{2}$ and Alberta, underfunding of school boards and cuts to teaching positions are widely contested by schools, school boards, and members of the public (Ferguson, 2019; People for Education, 2020). Moreover, Canadian federal investments in Indigenous learners consistently lag behind financial resources provided to non-Indigenous learners (CMEC, 2010; Malatest \& Associates, 2010). As such, governments at the federal and provincial levels must be reminded to fulfill their

2 As of late January 2020, there are currently teacher strikes and walkouts rotating daily throughout Ontario. Strikes are in response to the Ford government's underfunding of education, including plans to eliminate over 10,000 teachers through increased class-sizes (People for Education, 2020). 
fiduciary responsibilities to Indigenous students. Prospective Indigenous teacher candidates require more funding to access Canadian TEPs, TEPs require more funding to provide adequate support services, and school boards require increased funds to hire more Indigenous teachers.

\section{Strategy 2: Identifying Community Needs and Collaborating Over Practicum Placements}

Unlike the findings for Strategy 1, the study found a successful strategy across many Canadian TEPs that engage in partnerships with education authorities ${ }^{3}$ and Indigenous communities. Together, the partners coordinate teacher practicum placements, which best enables the identification of schools who require Indigenous teachers. Various Canadian TEPs coordinate with Indigenous communities and education authorities to fill specific community needs, training students with certain teaching positions in mind.

Programs that have the highest employment rates for Indigenous graduates have students complete their practicums in their home communities. In these programs, students complete their practicum in schools with the notion that they will be employed in that school following graduation (CMEC, 2016). An example includes the Nunavut Teacher Education Program (NTEP) for Inuit teacher candidates, operating through a partnership between the University of Regina and Nunavut Arctic College. This approach prepares Nunavummiut to teach in Nunavut schools. Indeed, according to Nunavut Arctic College (2016), the "majority of graduates of the Nunavut Teacher Education Program are employed within the school system in Nunavut" (n.p.).

Other programs that utilize this strategy report similarly successful outcomes. Examples include TEPs run by Brandon University, Nipissing University, University of Alberta, University of Winnipeg, and St. Francis Xavier University (St. FX). For example, through a partnership with Mi'kmaw Kina'matnewey, St. FX offers the community-based Mi'kmaq Teacher Education Program. Operating since 1995, the TEP was created in response to unmet demand and requests from Mi'kmaw Communities for Mi'kmaw teachers (St. FX, 2017). Mi'kmaw teacher candidates complete 22 weeks of practicum

3 Education authorities may include: Indigenous school boards, education councils, band schools, or provincial schools who serve a large Indigenous student body. 
in their home community, or, if preferred, in a school closer to St. FX. In an assessment by St. Francis Xavier Univesrity (Orr \& Cameron, 2004), it is stated that "between 1998 and 2004, almost 40 Mi'kmaq teachers received B.Ed. degrees; many are now working in Mi'kmaw Kina'matnewey schools, teaching their language and culture as part of their pedagogy." By 2009, St. FX had prepared 100 Mi'kmaw teachers for work within provincial and band-operated schools (St. FX, 2017).

Similarly, the University of Alberta's Aboriginal Teacher Education Program (ATEP) trains its students with the objective of having them placed in rural areas. Students complete two years of course work, followed by two years of professional training in schools close to home. The aim is to find employment for the students in these communities. According to Angela Wolfe, Associate Director of ATEP, "the program has graduated more than 200 elementary school teachers in the last 15 years, and about 90 per cent are working where they'd hoped" (as quoted in French, 2017).

\section{Strategy 3: Providing Ongoing Support for Newly Placed Teachers}

The data revealed a range of programs that in some way provide support for newly employed Indigenous teachers, particularly during their first year of employment. Of the case countries, this support was found the most in the United States. Forms of support included access to professional development courses and workshops, mentorship programs, and peer support programs. For example, the University of Oregon's Sapsik'wałá (Teacher) Education Program offers a full year of support services after graduation. Services include "provision of a mentor, formative evaluations of teaching, support for attendance at a professional conference, cohort seminar meetings, an electronic distribution and discussion list, and access to the virtual curriculum and research center" (University of Oregon, 2012). The ongoing support strategies were found in similar instances in Australia and New Zealand. Once again, the data were not mirrored in Canada, where TEP support commonly ceases after teacher graduation. The study suggests that this strategy is useful for TEPs to enact, especially where problems of beginner teacher attrition are prominent. 


\section{Discussion}

To help increase the number of Indigenous teachers working in schools across the case countries, and other countries not included in this study that face similar issues, Strategies 1 to 3 should be enacted by TEPs to help ease Indigenous teachers into new teaching roles. Increasing the number of Indigenous teachers is important for the operation of schools in remote Indigenous communities, especially as these schools tend to face issues of chronic understaffing (Caruk, 2018; Hall, 2012; Somerville \& Rennie, 2012). For instance, Kisemattawa Kiskinwahamakew Kamik School in northern Manitoba in Canada had only half of the teachers it required in recent years, even asking students to stay home at the beginning of the 2017 school term (Caruk, 2018; Coubrough, 2017; Landertinger et al., 2020). Albeit a small piece of what must ultimately be a massive collective effort on behalf of governments and education bodies, Strategies 1 to 3 should be applied by TEPs so as to contribute what they can in supporting their Indigenous teacher graduates in their new teaching positions (Strategy 3). The study found that supporting and even creating teaching positions (Strategy 1) for Indigenous teachers in their home communities, by collaborating with Indigenous education authorities (Strategy 2), can be effective tools for helping to staff remote Indigenous schools.

Strategies 1 to 3 are not only important for understaffed areas; implementing Strategies 1 to 3 would be beneficial for any area that has Indigenous students, since Indigenous teachers are closely linked to the educational well-being of Indigenous students. Indigenous teachers are better able to relate to Indigenous students' experiences, including experiences of colonialism, racism, and "otherness" (Landertinger et al., 2020; Somerville \& Rennie, 2012). Indigenous teachers are better able to counteract and expand beyond Eurocentric curricula and teaching models, shown to be an important factor in supporting Indigenous students (CMEC, 2010; Hickling-Hudson \& Ahlquist, 2003; Malatest \& Associates, 2010). And, when employed in their home communities, Indigenous teachers' knowledge of the local language can lessen barriers to participation, including oral and written communication for Indigenous students (Somerville \& Rennie, 2012).

High teacher turnover causes instability, negatively affecting "key factors for school functioning and improvement, which in turn can negatively impact student achievement" (Holme, 2018, p. 62). High rates of teacher turnover place greater financial burden on the schools and school boards. Milanowski and Odden (2007) estimate that 
training a new teacher costs American school districts upwards of \$10,000 USD. In Australia, rough estimates place teacher attrition rates at 30 to $50 \%$ in their first five years of teaching (Weldon, 2018). ${ }^{4}$ For Hall (2012), "high turnover of teachers in remote Indigenous community schools in the Northern Territory has long been considered a significant contributing factor to low academic outcomes for students in those communities" (p. 187).

This study is premised on Indigenous teachers as part of the solution to high teacher turnover. Indigenous teachers are more likely to remain in remote Indigenous schools and communities than non-Indigenous teachers (Fovet \& Hall, 2012; Hall, 2012). For instance, research by Hall (2012) refers to Indigenous teachers and staff employed in Australia's Northern Territory as "Stay and Stay and Stay" (p. 187) teachers, with many working in their local school systems for decades. On the other hand, "Come and Go" (p. 187) syndrome is used to describe the high teacher turnover rates primarily attributed to non-Indigenous teachers.

Our study found that Strategies 1 to 3 have each been effectively implemented by various TEPs to help with teacher retention. The findings intersect with strategies discussed by Yarrow and colleagues (1999), including "more effective partnerships between universities, departments of education and community members and organisations; the development of internships and mentoring programs; and the specific targeting of members of the rural and remote communities" for teacher training, as they are "more likely to take up and remain in rural and remote teaching positions" (Yarrow et al., 1999, p. 11). Providing ongoing support (Strategy 3) is reflected by Cherng and Halpin (2016), who advocate "strong administrative support for minority educators" (p. 417).

When TEPs are able to collaborate with Indigenous communities over Indigenous teacher practicums and placements (Strategies 1 and 2), Indigenous teachers are more likely to be trained in their home communities. Several TEPs employed the strategy of partnering through practicums in teacher candidates' home communities, leading to employment within these communities afterward, as well as numerical increases in employed Indigenous teachers and employed Indigenous teacher graduates. These programs include MATSITI and University of Nebraska-Lincoln's ROOTS program. According to our data, Strategies 1 and 2 increase the likelihood of a teacher continuing on in their 
teaching role, which in turn increases the likelihood of a remote Indigenous community school having a teacher in the long term (Hall, 2012). Improved teacher retention provides a semblance of "stability" and "sustainability in education" (Hall, 2012, p. 187), which can lead to better quality teaching and learning (Holme, 2018). Overall, the TEP strategies outlined in this article underline the importance of continuing to devise, fund, and implement efforts to improve Indigenous teacher support and retention in schools. The continuation of the strategies in part relies on the continued research and ethical data collection regarding the outcomes and effects of each TEP strategy as discussed below.

\section{Limitations and Directions for Future Research}

To help achieve the goal of better retaining Indigenous teachers in schools, our study is limited by its focus on strategies for TEPs. TEPs make up only a small portion of factors that may help or hinder Indigenous teacher retention in schools. Beyond the first few years of teaching, it is more likely that district- and school-level issues will affect teacher turnover rates (Papay et al., 2017). However, only focusing on TEPs is what makes our study unique. The authors were unable to find any other studies asking the same questions about what TEPs themselves can do for Indigenous teachers after graduation. Further, the scope is limited by only exploring four case countries. Future research could expand to other countries, and/or continue exploring TEP strategies in the case countries, as data collection for the most part ceased in 2018. It is likely that there may be new TEP strategies across the case regions since 2019, which could be added to the study.

As our study primarily used publicly available data from reports, along with follow-up with relevant personnel, the study was limited by the lack of quantitative and qualitative figures to evidence outcomes for many of the TEP strategies. Notably, obtaining certain data, such as the number of teachers who identify as Indigenous, can pose a challenge. For example, the MATSITI report was "limited by some state education and Catholic and independent jurisdictions not collecting or not making available data on teachers' Aboriginal and Torres Strait Islander status" (Buckskin, 2016, p. 16). This study underlines that future research should explore ethical and reliable means for continuing to collect data. Ultimately, data are needed to establish meaningful targets, and to optimize 
strategies for Indigenous teacher support. Evaluating the success, and often funding or re-funding, of most TEP strategies included in our study relies on obtaining data.

\section{Conclusion}

This article assessed successful TEP strategies for helping to place Indigenous teachers and increase the likelihood of Indigenous teacher retention in their new teaching roles. By assessing data from TEPs across Canada, the United States, Australia, and New Zealand, this study found three main strategies. The first is to create teaching positions. It is a common and effective strategy, especially in the United States, for TEPs to work with communities in establishing teaching positions that their students then work toward. In such contexts, Indigenous candidates are trained with specific jobs in mind, usually in their home communities.

Strategy 2 is identifying community needs and collaborating over practicum placements, successfully applied by various Canadian TEPs. This strategy involves partnerships between TEPs and education authorities that work to serve Indigenous communities. Similar to Strategy 1, Strategy 2 should enable Indigenous teacher candidates to complete practicums in their home communities, increasing the likelihood that they will remain working in that school system. The third strategy that TEPs may offer is to provide ongoing support for their Indigenous teacher graduates. The study found evidence of success for support services offered or organized by TEPs, including mentorship and peer support programs, access to workshops, conferences, online resources, and cohort seminar meetings. This strategy was derived mostly from the American data, as the data are lacking for Canadian TEPs.

Strategies 1 to 3 should be combined with those for increasing the number of Indigenous students recruited into and graduating from TEPs. As outlined in Landertinger et al. (2020), Indigenous student recruitment strategies for TEPs are "bringing the education to the students, removing financial barriers, and providing alternative pathways to admission and certification" (p. 37), and student retention strategies are "creating Indigenous cohorts, providing specialized support services, providing Indigenous-centric curriculum and program design, drawing from Indigenous pedagogies, and hiring Indigenous faculty and educators" (p. 37). 
Together, these strategies are a comprehensive picture of what TEPs can do to support an increase in the number of Indigenous teachers. The goal of increasing the number of Indigenous teachers is important for various reasons discussed in this article, including for supporting the well-being of Indigenous students (Battiste \& McLean, 2005; CMEC, 2010; Malatest \& Associates, 2010; Whitinui et al., 2018) and for staffing schools in chronically understaffed Indigenous communities (Hall, 2012; Landertinger et al., 2020; Somerville \& Rennie, 2012; Yarrow et al., 1999). That goal aligns with reconciliation commitments in the case countries of Australia, Canada, and New Zealand.

Finally, for TEP strategies to be enacted, adequate funding from district and regional bodies of education, and provincial and federal governments, is required. To best encourage such funding, this study calls on the continuation and improvement of ethical data collection. Data are required for continued research and analysis of strategies, for evidence of success, or areas that need improvement. The process enables a positive feedback loop, where such research allows the continued funding of programs, and for faculties of education, governments, school boards, Indigenous education authorities, and communities to work together to set realistic targets and timelines. Together, continued funding, research, and collaboration enables the best hope for increasing the number of Indigenous teachers. 


\section{References}

Anthony-Stevens, V., Stevens, P., \& Nicholas, S. (2017). Raiding and alliances: Indigenous educational sovereignty as social justice. Journal of Critical Thought and Praxis, 6(1), 18-37.

Arksey, H., \& O’Malley, L. (2005). Scoping studies: Towards a methodological framework. International Journal of Social Research Methodology, 8(1), 19-32.

Association of BC Deans of Education. (2018). Indigenous teacher education in British Columbia: Accomplishments, plans and prospects. http://www.educ.sfu.ca/abcde/ aboriginal.html

Battiste, M., \& McLean, S. (2005). State of First Nations learning. Canadian Council on Learning. http://en.copian.ca/library/research/ccl/state_first_nations_learning/ state first nations learning.pdf

Brandon University. (2020). Message to non-PENT students. https://www.brandonu.ca/ pent/message-to-non-pent-students/

Buckskin, P. (2016). More Aboriginal and Torres Strait Islander teachers initiative: Final report. (No. 1.0). University of South Australia. https://www.edutech.com.au/ matsiti/wp-content/uploads/2020/06/MATSITI-2016-Final-Report-1.0.pdf

Caruk, H. (2018, September 12). Rural students go to school without teachers as remote communities struggle to find staff. CBC News. https://www.cbc.ca/news/canada/ manitoba/rural-manitoba-first-nations-teachers-shortage-1.4819840

Cherng, S. H. Y., \& Halpin, P. F. (2016). The importance of minority teachers: Student perceptions of minority versus White teachers. Educational Researcher, 45(7), $407-420$.

Coubrough, J. (2017, September 19). Feds mull 'take-home packages'for Shamattawa students out of school due to teacher shortage. CBC News. https://www.cbc.ca/ news/canada/manitoba/shamattawa-school-closure-1.4297008

Council of Ministers of Education. (2010). CMEC summit on Aboriginal education - Strengthening Aboriginal success. https://www.cmec.ca/Publications/Lists/ Publications/Attachments/221/aboriginal_summit_report.pdf 
Council of Ministers of Education. (2016). CMEC Aboriginal educators' symposium:

Summary report. https://www.cmec.ca/Publications/Lists/Publications/ Attachments/359/CMEC-Aboriginal-Educators-Symposium-2015-EN.pdf

Ferguson, E. (2019). UCP budget freezes K-12 education funding, cuts post secondaries. https:/calgaryherald.com/news/local-news/ ucp-budget-freezes-k-12-education-funding-cuts-post-secondaries

Fovet, F., \& Hall, L. (2012). The lonesome road: A comparative study of low retention of teachers working in Aboriginal and SEBD contexts. Global Education Review, 1(1), 9-20.

French, J. (2017). Expanded U of A program to train Indigenous teachers for urban schools. Edmonton Journal. https://edmontonjournal.com/news/local-news/ expanded-u-of-a-program-to-train-indigenous-teachers-for-urban-schools

Hall, L. (2012). The 'come and go' syndrome of teachers in remote Indigenous schools: Listening to the perspective of Indigenous teachers about what helps teachers to stay and what makes them go. Australian Journal of Indigenous Education, 41(2), $187-195$.

Hickling-Hudson, A., \& Ahlquist, R. (2003). Contesting the curriculum in the schooling of Indigenous children in Australia and the United States: From Eurocentrism to culturally powerful pedagogies. Comparative Education Review, 47(1), 64-89.

Holme, J. J., Jabbar, H., Germain, E., \& Dinning, J. (2018). Rethinking teacher turnover: Longitudinal measures of instability in schools. SAGE Publications.

Kirkness, V. (1999). Aboriginal education in Canada: A retrospective and a prospective. Journal of American Indian Education, 39(1), 14-30.

Kitchen, J., \& Raynor, M. (2013). Indigenizing teacher education: An action research project. Canadian Journal of Action Research, 14(3), 40-58.

Landertinger, L., Tessaro, D., \& Restoule, J. P. (2020). "We have to get more teachers to help our kids": Recruitment and retention strategies for teacher education programs to increase the number of Indigenous teachers in Canada and abroad. Journal of Global Education Research, 5(1), 36-53. https://www.doi. org/10.5038/2577-509X.5.1.1066 
McKinley, E. A., \& Smith, L. T. (Eds.). (2019). Handbook of Indigenous education. Springer.

Milanowski, A. T., \& Odden, A. R. (2007). A new approach to the cost of teacher turnover. Center on Reinventing Public Education. https://www.crpe.org/sites/ default/files/wp sfrp13 milanowskiodden aug08 0.pdf

Miller, J. (2020, January 27). What are the issues in the dispute with Ontario high school teachers planning a one-day strike? Ottawa Citizen. https://ottawacitizen.com/ news/local-news/what-are-the-issues-in-the-dispute-with-ontario-high-schoolteachers-planning-a-one-day-strike

Murray-Orr, A., \& Mitton-Kukner, J. (2017). An exploratory case study of one early career teacher's evolving teaching practice in Northern Canada. McGill Journal of Education, 52(1), 71-92.

Nardozi, A., Restoule, J. P., Broad, K., Steele, N., \& James, U. (2014). Deepening knowledge to inspire action: Including Aboriginal perspectives in teaching practice. In Education, 19(3), 108-122. http://ineducation.ca/ineducation/article/ view/140/623

National Indian Education Association. (2018). Sovereignty in education: Creating culturally-based charter schools in Native communities. https://www.niea. org/charter-school-framework? rq=Sovereignty $\% 20$ in $\% 20$ education $\% 3 \mathrm{~A} \% 20$ Creating\%20culturally-based $\% 20$ charter $\% 20$ schools $\% 20$ in $\% 20$ Native $\% 20$ communities

Nunavut Arctic College. (2016). 2016/17 Nunavut Teacher Education Program (NTEP). https://arcticcollege.ca/education

Orr, J., \& Cameron, C. (2004). “We are Mi'kmaw Kina'matnewey”: An assessment of the impact of the Mi'kmaw Kina'matnewey self government agreement on the improvement of education for participating Mi'kmaw communities. St. Francis Xavier University.

Papay, J. P., Bacher-Hicks, A., Page, L. C., \& Marinell, W. H. (2017). The challenge of teacher retention in urban schools: Evidence of variation from a cross-site analysis. Educational Researcher, 46(8), 434-448. https://doi. org/10.3102/0013189X17735812 
People for Education. (2020). Labour issues in Ontario education. https:// peopleforeducation.ca/our-work/labour-issues-and-timelines-in-ontario-education/

Program for the Education of Native Teachers. (2015). P.E.N.T. student handbook 2015-2016. Brandon University. https://studylib.net/doc/9561963/ pent-student-handbook

Malatest \& Associates (Eds.). (2010). Promising practices: Increasing and supporting participation for Aboriginal students in Ontario. Higher Education Quality Council of Ontario. http://www.heqco.ca/SiteCollectionDocuments/ Promising\%20Practices.pdf

Reconciliation Australia. (2016). The state of reconciliation in Australia summary: Our history, our story, our future. Reconciliation Australia. https://www.reconciliation. org.au/wp-content/uploads/2017/11/State-of-Reconciliation-Report SUMMARY. pdf

Somerville, M., \& Rennie, J. (2012). Mobilising community? Place, identity formation and new teachers' learning. Discourse: Studies in the Cultural Politics of Education, 33(2), 193-206.

St. Francis Xavier University. (2017). Bachelor of education: Mi'kmaq specialization. https://www2.mystfx.ca/bachelor-of-education/mikmaq-specialization

Stauffer, B. (2017). University of Nebraska-Lincoln, College of Education and Human Sciences: Changing lives in Native American communities. https://cehs.unl.edu/ cehs/changing-lives-native-american-communities/

Truth and Reconciliation Commission. (2015). Honouring the truth, reconciling for the future: Summary of the final report of the Truth and Reconciliation Commission of Canada. Queen's Printer.

Truth and Reconciliation Commission of Canada. (2015). Truth and Reconciliation Commission of Canada: Calls to action. http://trc.ca/assets/pdf/Calls to Action English2.pdf

University of Oregon. (2012). Sapsik'watá teacher education program. education. uoregon.edu/sapsikwala 
US Department of Education. (2017). Indian education: Formula grants to local education agencies. https://www2.ed.gov/programs/indianformula/index.html

Weldon, P. (2018). Early career teacher attrition in Australia: Evidence, definition, classification and measurement. Australian Journal of Education, 62(1), 61-78. https://doi.org/10.1177/0004944117752478

Whitinui, P., Rodriguez de France, C., \& McIvor, O. (Eds.). (2018). Promising practices in Indigenous teacher education. Springer.

Wong, J. (2020, April 30). Frustrated parents in Ontario pivot from official distancelearning program amid COVID-19. CBC News. cbc.ca/news/canada/toronto/ parents-opt-out-distance-learning-1.5548215

Yarrow, A., Ballantyne, R., Hansford, B., Herschell, P., \& Millwater, J. (1999). Teaching in rural and remote schools: A literature review. Teaching and Teacher Education, $15,1-13$.

Zingg, L. (2019). Promoting Indigenous sovereignty through education.

Teach for America. https://www.teachforamerica.org/stories/ promoting-indigenous-sovereignty-through-education 